間宮海峡は現在の千島一カムチャッカ海淟と平行 していず，あたかもサブダクションと無関係にみ える。また，日本海はプレート収斂境界として はチリ型とされ，押し縮められる地域である (UYEDA and KANAMORI 1979)にもかかわらず 開こうとしていることになる。さらに, 大陸を割っ て発達している活動的な海は世界でも数少なくな いが，そのような所は大洋中央海嶺が大陸に割っ て入った所に形成されている例が多い。以上の点 からみると，本域のそれも，大洋中央海嶺が大陸 に割って入ってきているという解釈が成り立つ。 そうとすれば，北極までのびてきている大西洋中 央海嶺の延長が間宮海峡を通り日本海を抜け沖 粴トラフまで延長しているという見方もできる (Fig. 1)。そして，その南方終点は，そこから南 は現在プレートの衝突の場である点から, 台湾北 端付近となろう。ただ，プレート回転の極の一方 が北極付近にあり，大西洋と反対側は閉じる領域 となるという見方をすると回転の極を超えて反対 側に海嶺がのびることは不合理にみえる。しか し，他の海嶺系のほとんどが，これまで考えられ ていたような大西洋海嶺系のような回路を作って
はいないことから、これについても疑問が残る。

\section{引用文献}

藤田至則・雁沢好博 (1982)：日本海の成立. 星野通平・柴崎達雄（編）：日本海の地犋, p. $37-58$.

伊勢崎修弘 (1985)：日本海の地磁気異常. 1985年 1 月 31 日 DELP 分科会で発表(於 東大地震研究所).

兼岡一郎 (1985)：日本海岩石の同位体と年 代. 「日本海・日本海溝の海底微細構造に 関するシンポジウム」で講演（於 東大海 洋研究所).

木村政昭・古川雅英・北沢久和 (1983)：フィ リピン海の西北核一琉球海㩐一。月刊海洋 科学, 15, p. 453-458.

KIMURA, M. (1985): Back-arc rifting in the Okinawa Trough. Marine and Petroleum Geology (in press).

氏家 宏(1982)：堆皘物と古生物（特に微化 石）より見た日本海の地史. 星野通平・柴 崎達雄(編): 日本海の地犋, p. 377-408.

UYEDA, S. and KANAMORI, H. (1979): Back-arc opening and the model of subduction. J. Geophys, Res. 84, p. 10491061.

富士川断層北方延長部の調查研究

恒 石 幸 正*

\title{
Study of the Northern Extension of the Fujikawa Fault \\ Related to the Future Tokai Earthquake
}

Yukimasa TSUNEISHI

富士川断層は 7 年前の1978年に発見された。発 見の経緯は次のようである。駿河湾周辺の海底地 形図を眺めていたとき，駿河トラフの中軸を走る 駿河湾断層は従来考えられていたようなフィリッ ピン海プレートのもぐり込みによる逆断層ではな く，むしろ左横すべり断層と考えた方が自然では ないだろうかと感じた。こう考えれば，伊豆半島 で最近数十年間に出現した数々の地震断層の走向
や変位センスとよく調和する。駿河湾断層が基本 的に左横すべり断層であることは，その後の海底 地質構造の調査結果によって裏付けられてきてい ると私には思える。詳細については拙著「東海地 震に関連する特 A 級活断層」(第四紀研究, 第 23 巻（1984） 2 号）を参照していただきたい。

この駿河湾断層が駿河湾の北でどこに上陸する だろうと考えている頃, 偶然, 私は環境アセスメ

* 東京大学地震研究所 Earthquake Research Institute, University of Tokyo 
ントセンターの塩坂邦雄氏に出合った。彼は富士 川の河口部に, 安政の地震によって生じた「地震 山」というものがあり，付近の河原には富士山の 溶岩が露出しているので, そこへ続くのではない かと言った。直ちに二人で調查してみると，ほか にもいくつかの断層の証拠を見付けることができ た。最も著しいものは, 富士山腹の谷の中で発見 した断層露頭である。断層面上には水平方向の擦 痕が明瞭に付いており，その形態は左横すべり運 動を示していた。このようにして，富士川河口に 上陸した駿河湾断層は, 富士山の西側斜面を横切 って北上することが推定され，この陸上部分の断 層に対して「富士川断層」と命名することにな った。後に分かったことであるが，富士川河原の 溶岩や地震山の存在は, 寸でに何人かの研究者に よって知られていたが，それが大きな左横すべり 断層に付随する現象であろうとは予想されていな かった。

地震山が安政東海地震（1854年）の際に生じた ものであることから, 次の東海地震も富士川断層 の活動によって起こると考えざるを得ない。東海 地震に関して, 従来は漠然と東海地域が危ないと 考えられていたのであるが，富士川断層の発見に より地震の発生源が確定されたわけである。

歴史的にみて, 東海地震は 150 年から 200 年の 間隔でくり返し発生してきている。安政の地震 （1854年）とひとつ前の宝永の地震（1707年）と の間は 147 年である。そして安政の地震から現在 までに 131 年が経過している。十年単位で考える ならば，富士川断層はいつ再活動してもよいだけ のエネルギーを蓄えている可能性が高い。富士川 断層の全貌を浮き彫りにする調査が急がれるわけ であるが，あるいは調查中に地震に見舞われる危 険性も皆無とは言えない。断層の精密調查に先行 して，この断層を用いた地震予知の観測体制をつ くることの方が重要であると判断された。

このような考えのもとに，1981年から 2 年間 は, 光波測量によって富士川断層の動きを監視す るシステムを設置する作業を行なってきた。この 倠測体制は, 富士川町, 富士宮市, 富士市の 3 地 域に光波測量の観測点を設け, 長さ数 $\mathrm{Km}$ 程の, 合計14本の測線を地元の御協力を得て連日観測す
るものである。早期に設置された測線について は，すでに 4 年間の実績があり，断層周辺の地殻 の動態が 把握されてきている。解析結果による と, 富士川断層周辺の地殼は北西一南東方向に短 縮され，4年間で $1.4 \times 10^{-6}$ 剪断歪が蓄積された ことがわかる。年平均の歪速度は $0.35 \times 10^{-6}$ とな り, この值は明治以降の三角測量から得られてい る值 $0.36 \times 10^{-6}$ とよい一致を示している。この歪 蓄積の割合は，150 年間で地殼の 限界歪量 $4.7 \times$ $10^{-5}$ に達することになるが，少くとも今の富士川 断層は異常な歪の進行を示していないと言ってよ い。

富士川断層の監視システムが軌道に乗った次の ステップとして, 観測の維持と合せて富士川断層 の再調查にとりかかるべき時点で, 東京地学協会 より「地学に関する研究調査助成」が与えられる ようになったことは幸甚であった。ここに感謝の 意を表する。

富士川断層の調査にあたって，当初は断層の延 長が予想される山梨県・長野県側の調査を考えた のであるが，方針を変更し，最南端の富士川河口 を出発点とし，そこから北方へ向けて詳しく調査 し直すこととした。それは, 富士川河口部では, 断層の発見以来, 各機関による新たな調査結果が 出されてきていたので, もう一度見直し調查をす る必要があったからである。以下に調査結果の概 要を南から北へ順に記す。

富士川断層の最南端は, 海底地質構造の延長と 安政地震時の地款変動から判断して, 吹上の浜の 富士川右岸堤防傍の河川敷にあると推定される。 断層は, ここから右岸堤防沿いに北上し, 蒲原町 の「地震山」の東側を通って新幹線の鉄橋を横断 する。この箇所では, 国鉄のボーリング調査によ り, 鉄橋の西詰から約 $100 \mathrm{~m}$ 東へ寄った地点を通 ることが確認されている。断層の東側, $-150 \mathrm{~m}$ 深では 新富士火山最初期の大淵溶岩 $(13,760 \pm$ $300 \mathrm{y} . \mathrm{BP})$ の存在が確認されている。断層の西側 では同溶岩は地下には存在せず，恐らく空中のレ ベルにあったものと考える。

東海道線の鉄橋下では，ほぼ川の中央部を通過 することが同じく国鉄の調查で確認され，断層の 東側の $-130 \mathrm{~m}$ 深に大淵溶岩が存在することが分 
かった。同溶岩は，鉄橋のすぐ上流の河床に背斜 構造をなして露出し, そのレベルは $+15 \mathrm{~m}$ であ る。

断層はこれより左岸へ渡り, 江戸時代初期に築 造された傩堤の先端を横切り, 約 $10 \mathrm{~m}$ の左ずれ 変位を与えている。この地点の東側で実施された 建設省のボーリング結果では， $-94 \mathrm{~m}$ 深で古富 士泥流の上面がとらえられており，断層の鉛直落 差は $120 \mathrm{~m}$ である。南の東海道線の籄所での鉛直

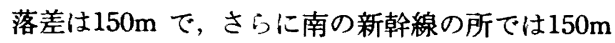
以上であるから，富士川断層の東下がりの鉛直落 差は南へ増大することになる。

東名高速道を渡った地点に富士市のボーリング 孔があり，-60m 深に大淵溶岩がとらえられて いる。断層は松岡にある, もうひとつの地震山と この地点との間を通るはずである。

富士川断層はこの先で入山瀬断層を横断し, 星 山丘陵に入るが, 石の宮の発電所傍で丘陵を外れ て潤井川を渡る。断層によって横断された星山丘 陵の平面形には 2 300m の左ずれが認められる。 星山丘陵では導水トンネルの中で断層が確認され ているほか, 小さな河川の左ずれオフセットが残 されている。星山丘陵の北方では, 断層の東下が りの落差はなくなり, ほとんど純粋の横すべり断 層となる。

潤井川を渡った断層は天間の市街地では比高 1 2 m の西下がりの低崖にそって北上し, 福泉 寺川入入る。ここではかつて小川賢之助氏により 断層露頭が観察されたが，今は見えない。

富士宮市若宮では, 古富士泥流からなる丘陵が $300 \mathrm{~m}$ 左ずれにくいちがって出来たと考えられる 崖が存在する。この北では，断層は新梨の西方を 通り, 西ヶ原の東で入山瀬溶岩を $300 \mathrm{~m}$ 左ずれに ずらしている。この溶岩の年代は不明であるが, 津屋弘迬氏の溶岩層序では旧期の下位の方に属し
ており，最下位の大淵溶岩の年代から判断して約 1 万年前のものと考える。

神成の南西方では, 神成溶岩流を約 $50 \mathrm{~m}$ 左迴 りにずらしている。さらに, 日影林の西では元村 山溶岩流IVがやはり同程度ずれている。ここでは 溶岩流の上に小規模の 地溝状の凹地が 残ってい る。

社領では東上がりの崖が続き, その北では谷が $200 \mathrm{~m}$ 左ずれに曲がっている。篠坂でも東上がり の崖が続き,さらに北方では, カケスバタ西方に 崖が続く。さらに $1 \mathrm{~km}$ 余り北方の谷の中には天 母山溶岩を切る見事な断層露頭のあることを先に 述べた。

以上の調査結果をまとめてみると, 富士川断層 の左横すべり変位量は 1 万年前の基準面に関して $300 \mathrm{~m}$ と推定される。鉛直変位は南方で顕著にな り，150m 程度の東下がりである。このように富 士川断層は, 年平均約 $3 \mathrm{~cm}$ の左横すべり変位を もった特 $\mathrm{A}$ 級活断層であり，少なくとも過去 1 万 年間, 150-200年周期で大地震をひき起こし, 数 $\mathrm{m}$ 程度の変位を累積してきたと考えることができ る。

今回の調査において痛感したことは, 当地域の 調查では, 肉眼観察のみに頼った地表踏査には限 界があり，なかなか確信のもてる証拠を出し得な いという点であった。直線的な崖があっても，こ れが断層崖であるのか, 溶岩流の末端であるの か, あるいは侵食地形であるのかの判断に苦し み, 今でも後味の悪さが残っている。最近, 富士 川断層の調查には電磁気学的手法が有効であるら しいということになりつつある。地表踏査によっ て, 断層の通過が予測された地点を電磁気探査に よって検証するという形の調查手法により再度, 検討を加えてみたいと思っている。 